\title{
The Key Role of Institution Pressure on Green Supply Chain Practice and the Firm's Performance
}

\author{
Jirawat Wongthongchai iD, Krittapha Saenchaiyathon iD \\ Faculty of Business Administration and Accountancy, Khon Kaen University (Thailand) \\ jirajanefanclub@hotmail.com,skrittapha@gmail.com
}

Received: August 2019

Accepted: October 2019

\begin{abstract}
:
Purpose: This study was conducted to investigate the influence of isomorphism institutional theory on green supply chain management (GSCM) and firm performance by using the structural equation model (SEM).

Design/methodology/approach: The study used structural equation model (SEM) to explain the driving factors of reducing the impact of environmental processes on the firm.

Findings: Isomorphism institutional factors showed a statistically significant positive effect on GSCM practices. Moreover, GSCM practices showed a statistically significant positive effect on firm performance. Under the literature review, customer pressure and top management support are primary factors to achieve GSCM practices and potential to establish firm performance.

Research limitations/implications: First, the common hypothesizes do not provide insight into all the relationships that warrant additional inspection. Second, Thailand manufacturers have experiences pressures from foreign customers and competitors but they have opportunities to learn from them to better improvement GSCM practices.

Practical implications: Results may highlight pressure for greening and which more efforts are needed for GSCM practices. GSCM practices generally require more effort due to need for collaborating with customer and competitor. Thailand manufacturers are increasingly confronted with isomorphism institutional pressure to implement GSCM practices.
\end{abstract}

Social implications: It is useful the Thailand government promotes GSCM by creating an awareness of the benefits. GSCM can help to alleviate the question of the followers about implementing GSCM and decrease their risk association with the environmental adoption.

Originality/value: Research creates clarity of the relationship between isomorphism institutional pressures, top management support, and performance in Thailand, which is a developing country with environmental investment concerns that affect profits from the operations of the firm.

Keywords: isomorphism institutional theory, institutional theory, green supply chain management, GSCM practices, performance

\section{To cite this article:}

Wongthongchai, J., \& Saenchaiyathon, K. (2019). The Key Role of Institution Pressure on Green Supply Chain Practice and the Firm's Performance. Journal of Industrial Engineering and Management, 12(3), $432-446$. https://doi.org/10.3926/jiem.2994 


\section{Introduction}

Environmental management (EM) that begins from the initial product planning contributes to improving the manufacturing process to minimize the environmental impact and enhance productivity. Moreover, EM has become more prevalent with an expanded scope and when used in combination with supply chain management, referred to as green supply chain management (GSCM) (Delmas, 2002). GSCM has led to environmental sustainability, as well as business sustainability, by changing the way a business operates in compliance with the principles of EM. Changes include waste reduction in the industry, reducing energy use, reducing the use of natural resources, using resources that are environmentally friendly, knowledge creation, and training employees in management (Green, Whitten \& Inman, 2012; Ahi \& Searcy, 2013; Zhu, Sarkis \& Lai, 2007; Sheu \& Talley, 2011)

Many factors have placed pressure on green supply chain management to influence a change in the organization. Isomorphism institutional theory, which explains the pressure in green supply chain management include two factors: customer pressure and competitor pressure (Seuring \& Müller, 2008; Zhu, Sarkis \& Lai, 2008). Moreover, according to the resource base view theory, an organization has important resources, including features that are valuable, rare, difficult to imitate, and not easily replaced. These resources provide a competitive advantage for the organization. A factor that interests scholars in the study of environmental management is top manager support, which affects the performance of the business. However, leading up to green supply chain management practices, effective management must have a clear way to practice and be measurable, resulting in the expansion of the body of knowledge (Delmas \& Montiel, 2009; Zhu et al., 2007).

GSCM practices comprise 5 factors, internal environmental management (Klassen \& Johnson, 2004; Sarkis, Zhu \& Lai, 2011; Yu, Chavez, Feng \& Wiengarten , 2014), green purchasing, green manufacturing, green transportation (de Sousa Jabbour, Jabbour, Latan, Teixeira \& de Oliveira 2014; Klassen \& Johnson, 2004; Zhu et al., 2008b), and environmental design (Green Jr, Zelbst, Meacham \& Bhadauria., 2012; Zhu et al., 2008b). Zhu, Sarkis and Lai, (2013) found that GSCM practices affect a firm's performance. They also have a comparative advantage, which is consistent with the studies of de Sousa Jabbour et al. (2014), Zhan, Tan, Ji, Chung and Chiu (2018) and Choi and Hwang (2015), which show that GSCM practices play a key role in the green and positive influences on performance.

We aimed to study the influence of isomorphism institutional factors affecting GSCM practices and firm performance in firms that have been certified ISO 14000. This study has led to the elucidation and improvement of the knowledge of GSCM to benefit industries, firms and governments and to the use of their knowledge to advance green supply chain management in Thailand.

\section{Literature Review}

\subsection{Isomorphism Institutional Theory}

Isomorphism institutional theory explains the pressures that affect a firm to make changes. It can be applied to understand how a firm can develop implementation strategies for success. In the context of green supply chain management, members of a supply chain must perform to meet customer requirements and regulations set by the government (Zailani, Eltayeb, Hsu \& Choon Tan, 2012; Carter, Kale \& Grimm 2000; Rivera, 2004), implying that firms are pressured by both internal and external factors. Founders of the theory, DiMaggio and Powell (1983), describe the three forms of institutional pressure (Sarkis, Zhu \& Lai, 2011; Lai, Wong \& Cheng, 2006) as follows.

Coercive: Coercive pressure may be either intrinsic or extrinsic and comes from an agency that has the power to enforce. Coercive pressure tends to begin in laws, regulations, and practices. A firm that does not follow may be punished, possibly forced to undergo the harshest disciplinary action (Rivera, 2004).

Mimetic: Mimetic pressures result from the unpredictability of the situation and uncertainty of management. In response to environmental pressures externally, firms benchmark their own progress relative to their competitors, leading to imitation, especially of the more successful ones. This approach trends with similar practices across firms. The results of imitation can be recognized in the form of spreading similarities between firms (Aerts, Cormier \& Magnan, 2006). 
Normative: Firms are under pressure to define or form their own operations to achieve competitiveness and remain in the industry. Firms must have internal pressure to adjust to rules and regulations so that they run their business according to best practices, building standards in environmental management. Firm training consultation or associations of specialists build legitimacy and standards to establish understanding based on common interests and values within the firm (Ball \& Craig, 2010).

Isomorphism institutional theory describes the changes that appears within a firm because of circumstantial pressures. Given a firm that is effective, isomorphism institutional theory provides a description of 3 factors, top management support, competitor pressure, and customer support, to study.

\subsection{Top Management Support}

A firm that is well equipped to handle a green supply chain requires the understanding and knowledge of personnel within the firm itself. A lack of professional environmental knowledge and lack of capacity in environmental management at the professional level are common in organizations that strive to manage green supply chains (Ehrhart, 2004). For a firm to implement GSCM, it must overcome obstacles, such as a lack of professional knowledge of the environment within the organization, any lack of support from senior management, a lack of information, or a lack of financial or human resources (González-Torre, Álvarez, Sarkis \& Adenso-Díaz, 2010). The support of senior management is especially important because it is associated with strategic planning of the organization, a critical factor in many green supply chains (Zhu, Sarkis, Cordeiro, \& Lai, 2008a; Walker, Sisto \& McBain, 2008).

Top management's handling of their organization's policy and strategic management determines firm guidelines for operating in various fields to achieve goals. In addition to management's support expressed through policies, regulations, and the direction they take with the organization, the resources they make available to support operational activities are also important, including funds, manpower, and time. The management's support to make the supply chain green is critical to the success of GSCM (Dubey, Gunasekaran, Papadopoulos \& Childe, 2015; Luthra, Garg \& Haleem, 2015; Zhu et al., 2008a).

\subsection{Competitor Pressure}

A competitor is a business in the same target market. Industry competition creates pressure to improve process efficiency and product quality due to pressures from competition and the company's learning and ability to mimic competitors with better performance (Zsidisin, Melnyk \& Ragatz, 2005; O'Cass \& Weerawardena, 2010; Carter \& Carter, 1998; Christmann \& Taylor, 2001; Hsu, Tan, Zailani \& Jayaraman., 2013). GSCM is the integration of environmental management into the components of an organization. Firms need to stimulate changes in attitude and process management in the workplace to meet the goals of the firm and manage the green supply chain. This is a change from traditional supply chain management, which focuses on quality, cost savings, and the creation of added value. Thus, creating a corporate culture that focuses on the environment is very important to the success of GSCM and commits a competitive advantage (Harris \& Crane, 2002; Zhan et al., 2018).

\subsection{Customer Pressure}

Customer demand has been a major factor in pushing awareness of the impact of consumption on the environment to the global level and has contributed to the creation of requirements for environmental management. Customer relationships have involved collaboration in the design of products and processes, leading to the reduction of environmental impacts and eco-friendly product packaging. Partnering with clients can include publishing information on the firm's practices, on how products are designed to be environmentally friendly, and on waste management strategies (Zhu et al., 2008a; Vachon \& Klassen, 2006; Lo \& Leung, 2000). Thus, customers play a key role in the strategic decisions of a firm (Delmas \& Montiel, 2009).

Customer demand is an issue that is critical to strategic decision making of the firm. Responding to and meeting customer satisfaction are the driving factors affecting the business of GSCM (Dubey et al., 2015; de Sousa Jabbour, de Oliveira Frascareli \& Jabbour, 2015; de Sousa Jabbour et al., 2014; Jayaram \& Avittathur, 2015). 


\section{Green Supply Chain Management Practices (GSCM practices)}

Because of increasing environmental awareness worldwide, environmental requirements have been implemented widely. There is pressure on firms to create environmental practices as part of their core competencies to gain a competitive advantage and avoid violating regulations (Delmas \& Toffel, 2004). GSCM is associated with the production process, from raw material procurement to production to the recycling process (Green et al., 2012; Ahi \& Searcy, 2013; Zhu et al., 2007), and members of the supply chain must cooperate in managing the green supply chain (Eksoz, Mansouri \& Bourlakis, 2014).

The supply chain involves participation from several parties to meet the needs of customers, whether they are suppliers, transporters, warehouses, wholesalers, retailers, or the customers themselves (Eltayeb, Zailani \& Ramayah, 2011). The major focus of GSCM practices is to evaluate environmental performance according to set standards, gauge product quality and environmental impact, and estimate the costs of waste from the production process (Ferrón-Vílchez \& Darnall, 2016). Meanwhile, GSCM also integrates customer cooperation into environmental management. These activities help to reduce both direct and indirect impacts of products on the environment (Zhu et al., 2007; Sarkis et al., 2011).

GSCM is the integration of activities along the supply chain with environmental management. Implementation of GSCM is recognized as causing the expansion of management practices and operations. GSCM practices have 5 dimensions, internal environmental management (Klassen \& Johnson, 2004; Sarkis et al., 2011; Yu et al., 2014), green purchasing, green manufacturing, green transportation (de Sousa Jabbour et al., 2014; Klassen \& Johnson, 2004; Zhu et al., 2008a, 2008b), and environmental design (Green Jr et al., 2012; Zhu et al., 2008a, 2008b). A description of each element follows.

\subsection{Environmental Design}

Environmental design is the design of products to reduce the use of raw materials and energy throughout the supply chain. The product is designed with parts or components that can be reused, recycled, and recovered and is designed to avoid the use of hazardous materials and dangerous manufacturing processes (de Sousa Jabbour et al., 2014). Environmental design is the creation of products that are environmentally friendly by incorporating environmental considerations into the lifecycle of the product, from the purchasing of raw materials to the product's final form (Leal, Casadesús \& Pasola, 2003). If customers participate in a design review, this is beneficial because the products will be recognized by even more customers (Zhu et al., 2008a, 2008b; Spicer \& Johnson, 2004; Toffel, 2004; Petersen \& Kumar 2009).

\subsection{Internal Environmental Management}

Internal environmental management is a system comprising a series of environmental policies within a firm and is meant to evaluate the impact of the firm on the environment. There is targeted planning, operations, and a review of the firm's activities, making it accountable to its environmental responsibilities to pass monitoring by auditors (Darnall, Jolley \& Handfield, 2008). When GSCM is introduced into the company, the firm will perform environmentally friendly management of the business to support a green supply chain, total quality environmental management, a process of review and evaluation of environmental outcomes, as well as systemic environmental management within the firm. This can lead to the firm receiving ISO 14001 certification (Aravind \& Christmann, 2011).

\subsection{Green Purchasing}

Green purchasing is the supply of raw materials to produce the firm's products. Green purchasing considers environmental impact (Carter etal., 2000) by using life cycle assessment when selecting products and packaging. This encourages partners to participate in product design and packaging to reduce waste in the supply chain and in product design to facilitate reusing and recycling without sacrificing the features or quality of raw materials. Green purchasing includes collaboration with, as well as assessment, auditing, and certification of, partners to achieve success in GSCM (Min \& Galle, 2001; Zsidisin \& Siferd, 2001). 


\subsection{Green Manufacturing}

Green manufacturing refers to the process that seeks to bring the outdated and surplus assets into the reverse logistics process to restore these assets or distributor by selling materials and materials already in use, such as the sales of machines with more demanding applications, enabling firms to save costs and restore the value of the product (Green Jr et al., 2012). Moreover, this element includes cooperation in the design of the product that is environmentally friendly, clean production and environmentally friendly packaging (de Sousa Jabbour et al., 2014; Klassen \& Johnson, 2004; Zhu et al., 2008a, 2008b).

\subsection{Green Transportation}

Green transportation is not only oriented to reducing environmental impact, but it also a driver in firm performance. Particularly, green transportation is related to biological, monitoring, ICT and other specific technologies that can be applied to green transportation (Jumadi \& Zailani, 2010). In GSCM, green transportation is the set of actions taken and the relationship formed respond to environmental concerns regarding the distribution and transportation of the firm's good and services (Truffer \& Coenen, 2012). Consequently, the importance category of transportation defined to better respond to environmental regulation is the improvement of productivity based on the efficient use of resources (Porter \& Van der Linde, 1995). Nidumolu, Prahalad and Rangaswami. (2009) found that the growing importance of environmental concerns have influenced industry competitiveness, driving firms to change the way they view their activity, generally oriented to gain energy efficiency, reduce company dependence on fuels, and introduce renewable and green sources of energy (Archibugi \& Iammarino, 2002; Chen, 2008).

\section{Research Framework and Hypothesis}

A review of the literature shows that factors supporting a firm's green supply chain practices and affecting performance include internal and external pressures. The factors influencing GSCM practices include top management support, competitor pressure, and customer pressure. Institutional theory expounds on changes that can occur due to pressures. That is, a firm tends to adopt green training to improve GSCM practices and firm performance, as well as to improve the influence of market scope on the relationship between GSCM practices and firm performance. Therefore, GSCM practices and green training may have an impact on firm performance.

Top management support, competitor pressure, and customer pressure play important roles in pushing traditional management practices towards environmental management practices, as well as in promoting improved efficiency in management. Zhu et al., (2013) found that top management support, competitor pressure, and customer pressure lead to positive GSCM practices and improvements in the firm's performance. This is consistent with findings by Green et al. (2012), who showed that top management support, competitor pressure, and customer pressure are critical to the success of GSCM practices (Darnall, et al., 2008; Testa \& Iraldo, 2010). Zhu, Sarkis and Lai (2012) found that competitor pressure and customer pressure contribute to improving GSCM practices and firm performance.

Hypothesis 1: There is a positive relationship between top management support and green supply chain management practices.

Hypothesis 2: There is a positive relationship between competitor pressure and green supply chain management practices

Hypothesis 3: There is a positive relationship between customer pressure support and green supply chain management practices.

Hypothesis 4: There is a positive relationship between green supply chain management practices and firm performance. 


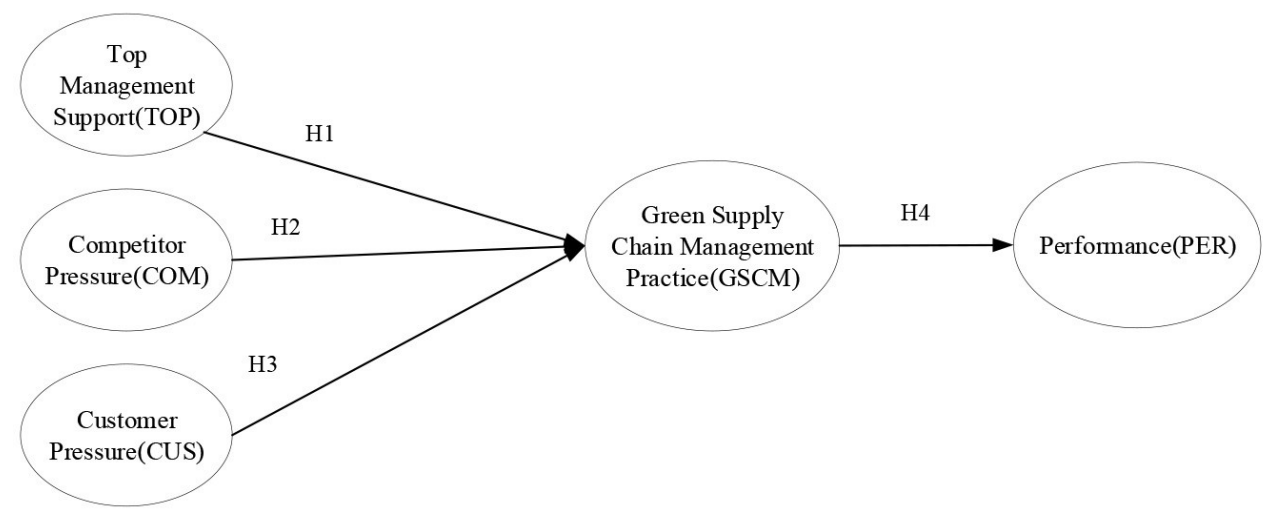

Figure 1. Conceptual Framework

\section{Research Methods}

The research population for this study are industrial firms in Thailand that have been certified with the ISO 14000 standard. The sample in this study comprises 286 firms. The response bias was checked; none was detected. Next, missing values were checked; no missing value was greater than $5 \%$, and 286 questionnaires could be used for data analysis in the next step (Lam, Kraus \& Ahearne, 2010; Homburg, Artz \& Wieseke, 2012; King, Lenox \& Terlaak, 2005).

\section{Measurement}

A measurement model and a structural model were used in this study. The measurement model assessed the relationship between observed variables and latent variables. However, the structural model assessed the relationship among latent variables. The variables comprised top management support (TOP), competitor pressure (COM), customer support (CUS), and firm performance (PER). All five variables were measured using the five-point Likert scale $(1=$ strongly disagree, $5=$ strongly agree $)$.

Green supply chain management (GSCM) practices has 5 dimensions, internal environmental management (Klassen \& Johnson, 2004; Sarkis et al., 2011; Yu et al., 2014), green purchasing, green manufacturing, green transportation (de Sousa Jabbour et al., 2014; Klassen \& Johnson, 2004; Zhu et al., 2008a, 2008b), and environmental design (Green Jr et al., 2012). All five variables were measured using the five-points Likert scale $(1=$ strongly disagree, 5 = strongly agree).

\section{Data analysis}

\subsection{Assessment of the Measurement Models}

To assess the measurement model, the reliability and validity of the construct were appraised. The indicators were used in industries; however, this study focused on firms in Thailand that have been certified with the ISO 14000 standard. Next, a repeated indicators approach was used for assessment, individual indicators alongside outer model loading, composite reliability (CR), and average variance extract (AVE). Hair et al., (2010) recommended a rule of outer loading relevance testing. For outer loading greater than 0.70 , the indicator should be retained. If the loading is greater than 0.40 but less than 0.70, the impact of indicator deletion on the value of CR and AVE of the construct should be analyzed. If deletion does not increase CR or AVE, the indicator should be retained on the other site. If deletion increased CR or AVE, it should be deleted from the measurement model.

\section{Results}

\subsection{Multicollinearity Analysis}

Multicollinearity analysis using Pearson's product moment correlation was used to measure the correlation between variables. Variables should not be too closely related with other to avoid errors in the analysis. The correlation coefficient should not exceed 0.8 , and a VIF value less than 5 represents an exceptional value (Hair, Black, Babin \& Anderson, 2010). The results showed no exceeded value of the correlation. The data showed no multicollinearity according to Table 1. 


\begin{tabular}{|c|c|c|c|c|c|c|c|c|c|}
\hline & top & com & cus & gop & ine & gpu & gma & gtr & per \\
\hline top & 1 & & & & & & & & \\
\hline com & $.746^{* *}$ & 1 & & & & & & & \\
\hline cus & $.685^{* *}$ & $.765^{* *}$ & 1 & & & & & & \\
\hline gop & $.740^{* *}$ & $.748^{* *}$ & $.707^{* *} *$ & 1 & & & & & \\
\hline ine & $.767^{* *}$ & $.705^{* *}$ & $.699 * *$ & $.726^{* *}$ & 1 & & & & \\
\hline gpu & $.712^{* *}$ & $.736^{* *}$ & $.717 * *$ & $.757 * *$ & $.702 * *$ & 1 & & & \\
\hline gma & $.685^{* *}$ & $.712^{* *}$ & $.662^{* *}$ & $.751^{* *}$ & $.722 * *$ & $.695^{* *}$ & 1 & & \\
\hline gtr & $.698^{* *}$ & $.732 * *$ & $.700^{* *}$ & $.722^{* *}$ & $.735^{* *}$ & $.698^{* *}$ & $.734^{* *}$ & 1 & \\
\hline gta & $.652^{* *}$ & $.701 * *$ & $.628^{* *}$ & $.720^{* *}$ & $.690^{* *}$ & $.667 * *$ & $.721^{* *}$ & $.673^{* *}$ & \\
\hline per & $.626^{* *}$ & $.634^{* *} *$ & $.619^{* *}$ & $.661 * *$ & $.635^{* *}$ & $.638^{* *}$ & $.604^{* *}$ & $.715^{* *}$ & 1 \\
\hline $\mathrm{ma}$ & $.692 * *$ & $.692 * *$ & $.669 * *$ & $.697 * *$ & $.721 * *$ & $.638^{* *}$ & $.702 * *$ & $.670^{* *}$ & $.704^{* *}$ \\
\hline VIF & 3.384 & 3.784 & 3.078 & 3.745 & 3.559 & 3.174 & 3.277 & 3.170 & - \\
\hline Mean & 6.184 & 6.013 & 6.014 & 6.098 & 6.097 & 6.048 & 6.003 & 6.028 & 5.869 \\
\hline SD & 0.842 & .943 & .950 & .940 & .906 & .929 & .943 & .876 & .860 \\
\hline CR & 0.892 & .900 & .877 & .897 & .907 & .835 & .893 & .866 & .837 \\
\hline AVE & .626 & .618 & .641 & .635 & .710 & .627 & .624 & .620 & .633 \\
\hline
\end{tabular}

** Correlation is significant at the 0.01 level (2-tailed).

Table 1. Correlations of the Variable and Descriptive Validity

\subsection{Assessment of the Structure Equation Model}

The aim of structural model analysis is to confirm that the conceptual framework aligns well with empirical analysis. The researcher analyzes the structural model to determine the model's consistency with empirical data and performs the model improvement using the MI (Modification index). The appropriate model comprises $\chi^{2}=2191.379, \mathrm{df}=1202.073, \mathrm{p}$-value $=0.000, \mathrm{GFI}=0.921$, AGFI $=0.923, \mathrm{CFI}=0.930, \mathrm{NFI}=0.926$, TLI $=0.926$, RMSEA $=0.048$, SRMR $=0.046$. By the model fit, indices meeting the criteria that GFI, AGFI, CFI, NFI, TLI should exceed 0.90, and RMSEA and SRMR should be less than 0.05.

The results indicate a positive relationship between top management support and green supply chain management practices $(\beta=0.840, \mathrm{p}<.01)$, a positive relationship between competitor pressure and green supply chain management practices $(\beta=0.862, \mathrm{p}<0.01)$, and a positive relationship between customer pressure support and green supply chain management practices $(\beta=0.933, \mathrm{p}<0.01)$. The results also demonstrate a positive relationship between green supply chain management practices and firm performance $(\beta=0.842, \mathrm{p}<0.05)$.

To sum the results of the hypothesis, the total effect, direct effect, and indirect effect are considered. Hair et al. (2010) recommend that, if the indirect effect is less than 0.08 , it is not mostly of interest. The total effect in the model is displayed in Table 2 .

\begin{tabular}{|c|c|r|r|r|r|r|c|}
\hline Hypothesis & $\begin{array}{c}\text { Hypothesized } \\
\text { Relationship }\end{array}$ & \multicolumn{1}{|c|}{ Estimate } & $\begin{array}{c}\text { Std. } \\
\text { Error }\end{array}$ & t-value & $\operatorname{Pr}(>$ lt1) & \multicolumn{1}{|l|}{ R2 } & Result \\
\hline H1 & TOP -> GSCM & .840 & .071 & 11.902 & .000 & .778 & Supported \\
\hline H2 & COM -> GSCM & .862 & .069 & 12.403 & .000 & .817 & Supported \\
\hline H3 & CUS -> GSCM & .933 & .075 & 12.418 & .000 & .757 & Supported \\
\hline H4 & GSCM -> PER & .842 & .113 & 7.467 & .000 & .730 & Supported \\
\hline
\end{tabular}

Table 2. Result of Hypotheses 


\begin{tabular}{|c|r|r|r|r|r|r|}
\hline & \multicolumn{3}{|c|}{ GSCM } & \multicolumn{2}{c|}{ PER } \\
\hline & Direct effect & Indirect effect & Total effect & Direct effect & Indirect effect & Total effect \\
\hline TOP & .840 & - & .840 & - & .708 & .708 \\
\hline COM & .862 & - & .862 & - & .726 & .726 \\
\hline CUS & .933 & - & .933 & - & .785 & .785 \\
\hline GTA & .902 & - & .902 & .029 & .760 & .789 \\
\hline
\end{tabular}

Table 3. Direct Effect, Indirec

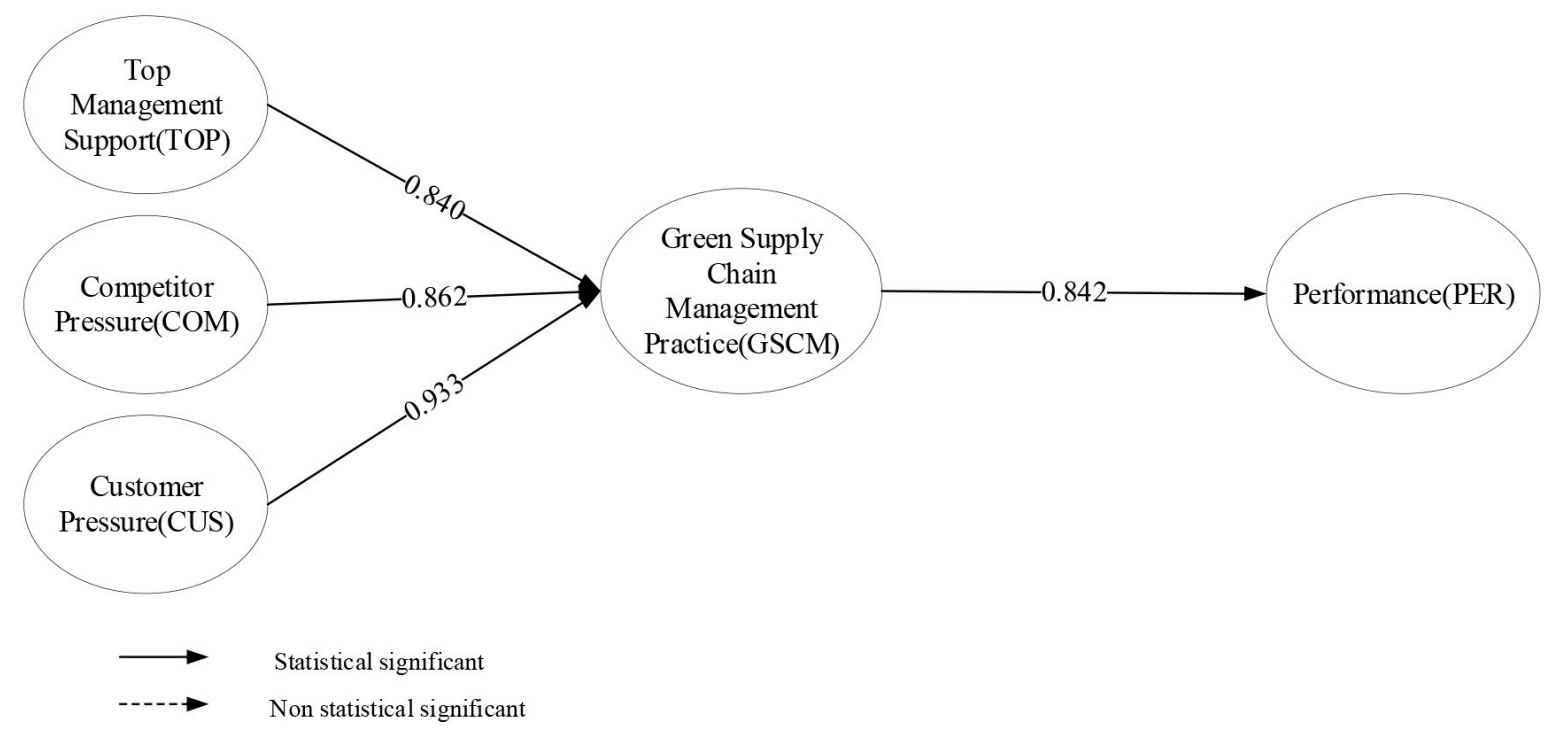

Figure 2. Results of the Structural Equation Model: Full Model

In this study, the impact of the variables was examined. Figure 2. explains that, in a particular path relationship, top management support (TOP), competitor pressure (COM), and customer pressure (CUS) have positive effects on green supply chain management practices (GSCM). In turn, green supply chain management (GSCM) practices have a positive effect on firm performance.

Accordingly, the loading of the latent variable green supply chain management (GSCM) practices is obtained from the 3 observed variables. Customer pressure (CUS) is the most important, followed by competitor pressure (COM) and top management support (TOP). Performance (PER) is obtained from green supply chain management (GSCM) practices.

The hypothesized and non-hypothesized relationships explain the best model for the present study. Figure 2 shows the suitable model that contributed to the present research. Isomorphism institutional theory is influentially and dominantly discussed to understand green supply chain management (Sarkis et al., 2011; Lai et al., 2006). Isomorphism institutional theory describes the pressures that influence a firm to make changes. The theory can be applied to understand how firms can develop implementation strategies for success. In the context of GSCM, members of a supply chain must operate to meet customer requirements and regulations set by the government (Zailani et al., 2012; Carter et al., 2000; Rivera, 2004), implying that firms are pressured both internally and externally. Founders of the theory, DiMaggio and Powell (1983), explained the three forms of institutional pressure (Sarkis et al., 2011; Lai et al., 2006): coercive pressure, mimetic pressures, and normative pressure.

Different transformative pressures can lead to a firm coping in various ways. Those within an organization may be reluctant to transform, but the firm will inevitably need to follow rules and regulations. Most firms become imitators by introducing practices similar to other firms, as this method has the advantage of not requiring a long learning period if the practices are suitable and transferable. However, a limitation of this approach is that each firm has a different culture. There is a need for improved methods of operation that are appropriate to each 
specific culture, and such methods cannot be solely imitated. When changing from the norm, if a practice cannot be adapted to the culture of the firm appropriately, the change may not succeed. Compliance practices or membership in professional societies that have been created out of compliance will be accepted in professional circles and associations. However, if conditions are not traditional or sufficiently flexible or if there is a lack of development opportunities, development of the firm in the future and GSCM as a result of all three forms of pressure may be hindered.

\section{Discussion}

For most manufacturers, particularly for those in developing countries such as Thailand, a major objective is to avert economic risk due to punishment from any environmentally oriented misconduct. Alternatively, proactive firms tend to seek improvement in economic performance through environmental practice such as GSCM practices. Overall, the empirical results show the relationship between top management support (TOP), competitor pressure (COM), customer pressure (CUS), GSCM practices (GSCM), to firm's performance (PER) exist, supporting development of a proactive stance on GSCM practices of firm.

\subsection{Isomorphism institutional pressure and GSCM practices}

This study shows that isomorphism institutional pressure and top management support generally relate to GSCM practices. Such results may highlight pressure for greening and which more efforts are needed for GSCM practices. GSCM practices generally require more effort due to need for collaborating with customer and competitor. Thailand manufacturers are increasingly confronted with isomorphism institutional pressure to implement GSCM practices (Zhu et al., 2013).

The findings indicate that top management support relates to GSCM practices. This result is not surprising since, the product life cycle, most of the environmental impact of product and processes are locked into the product at product design stage when product materials are selected and performance is largely determined (Lewis \& Harvey, 2001). Top management is a helpful, emerging tool to improve environmental performance by addressing function of product while minimizing life cycle environmental impacts. Emission reduction and energy saving has become an international strategy to achieve sustainable development. To decrease energy consumption, government has organized energy audits for manufacturers consuming excessive energy, and forced them to re-design their technologies and products (Zhu et al., 2008b). The success of GSCM practices requires top management support as well as isomorphism institutional pressure in the supply chain as a whole (Lewis \& Harvey, 2001). The finding (see Figure 2) shows that top management support may affect firm's performance through GSCM practices. This result implies product designers and developers are playing an important role, where cross-functional collaboration and green supply chain relationships should be encouraged.

The results show further that environmental management usually requires greater organizational efforts for improvement since firms need to cooperate and develop relationships with their suppliers and customers. Due to these requirements, top management must be committed and supported (Bansal, 2003). Support from top management is key to successful improvement of environmental practices (Carter \& Carter, 1998). Positive relationship between top management support and GSCM practices were found. Communication between top management and partners is also important in developing a successful firm and environment relationship (Apsan, 2000).

To promote cooperation for addressing regulatory among Thailand manufacturers, the Thailand government may establish supporting systems explaining how collaborations actually aid them in meeting regulation.

\subsection{GSCM and performance}

GSCM practices can lead to performance from relationship between GSCM practices and performance. The empirical results that positive relationship between GSCM practices and performance (González-Benito \& González-Benito, 2006). Isomorphism institutional pressure and top management support have indirect affect with performance. Top management requires capital investment while environmental operation such as decreases in expenses for energy 
consumption, and waste treatment. It is necessary to encourage its improvement by firms due to the major role of top management support in decreasing environmental burdens over the product life cycle (Zhu et al., 2008a, 2008b).

Customer pressure and competitor pressure have indirect affect with performance. The possible relationships exist for performance improvement through customer collaboration and competitive drivers. Performance is being reaped in long term profitability and sale performance (Bowen et al., 2006). Performance may be achieved after environmental improvements have occurred. Thus, a potential indirect path to achieve performance for Thailand manufacturers can be originated through isomorphism institutional pressure such as customer pressure and competitor pressure. With improving environmental image and operational performance, Thailand manufacturers can gain performance improvement in the longer term.

\section{Conclusions and future research}

In general, structural relationships exist among isomorphism institutional pressure, top management support, GSCM practices, and performance. The isomorphism institutional pressure for environmental concern has driven Thailand manufacturers to implement GSCM practices. The results suggest that GSCM practices do significantly affect performance by improved environmental practices. The isomorphism institutional pressure related to GSCM practices. Though top management may require increased environmental investment, it can be a resource for firms to gain economic benefit. Further, top management brings collaboration with customers and suppliers which can indirectly increase performance through environmental improvement.

Due to the requirement from customer pressure and competitor pressure, Thailand manufacturers have implemented GSCM practices. Such practices have directly brought performance improvement.

This study provides implication for both policy makers and manufacturers. It also opens research avenues for GSCM, environmental management, and isomorphism institutional theory. For implications, firms are given some insights into how they can improve performance from implementing GSCM. For example, firms need to understand relationship between isomorphism institutional pressure, top management support, GSCM practices, and performance and ensure that coordination of their activities to arrive at better environmental improvement for performance gain to be achieved. Policy makers and regulators can understand how to motivate firms to implement GSCM. Particularly, isomorphism institutional pressure is affecting improvement of GSCM in manufacturing. It is useful the Thailand government promotes GSCM by creating an awareness of the benefits. GSCM can help to alleviate the question of the followers about implementing GSCM and decrease their risk association with the environmental adoption.

\section{Limitations and Future Research Directions}

Limitation in the research exist, but limitations also provide directions and opportunities for future research

First, the common hypothesizes do not provide insight into all the relationships that warrant additional inspection. For example, one relationship is that government support encourages GSCM practices and firm performance. Second, Thailand manufacturers have experiences pressures from foreign customers and competitors but they have opportunities to learn from them to better improvement GSCM practices. The diffusion of environmental management from developed countries to developing countries such as Thailand should receive investigation and attention. It is worthwhile to explore the diffusion covering the green supply chain in related factor as international companies (Wong, Lai, Lun \& Cheng, 2012).

\section{Declaration of Conflicting Interests}

The authors declared no potential conflicts of interest with respect to the research, authorship, and/or publication of this article.

\section{Funding}

The authors received no financial support for the research, authorship, and/or publication of this article. 


\section{References}

Aerts, W., Cormier, D., \& Magnan, M. (2006). Intra-industry imitation in corporate environmental reporting: an international perspective. Journal of Accounting and Public Policy, 25 (3), 299-331.

https://doi.org/10.1016/j.jaccpubpol.2006.03.004

Ahi, P., \& Searcy, C. (2013). A comparative literature analysis of definitions for green and sustainable supply chain management. Journal of Cleaner Production, 52 (August), 329-341. https://doi.org/10.1016/j.jclepro.2013.02.018

Apsan, H.N. (2000). Running in nonconcentric circles: Why environmental management isn't being integrated into business management. Environmental Quality Management, 9(4), 69-75.

https://doi.org/10.1002/1520-6483(200022)9:4<69::aid-tqem7>3.0.co;2-3

Aravind, D., \& Christmann, P. (2011). Decoupling of standard implementation from certification: Does quality of ISO 14001 implementation affect facilities' environmental performance? Business Ethics Quarterly, 21(1), 73-102. https://doi.org/10.5840/beq20112114

Archibugi, D. \& Iammarino, S. (2002). The globalization of technological innovation: definition and evidence. Review of International Political Economy, 9(1), 98-122. https://doi.org/10.1080/09692290110101126

Ball, A., \& Craig, R. (2010). Using neo-institutionalism to advance social and environmental accounting. Critical Perspectives on Accounting, 21(4), 283-293. https://doi.org/10.1016/j.cpa.2009.11.006

Bansal, P. (2003). From issues to actions: The importance of individual concerns and organizational values in responding to natural environmental issues. Organization Science, 14(5), 510-527. https://doi.org/10.1287/orsc.14.5.510.16765

Bowen, F., Cousins, P., Lamming, R., \& Faruk, A. (2006). Horses for courses: explaining the gap between the theory and practice of green supply. In Greening the supply chain (151-172). Springer, London.

https://doi.org/10.1007/1-84628-299-3_9

Carter, C.R., \& Carter, J.R. (1998). Interorganizational determinants of environmental purchasing: initial evidence from the consumer products industries. Decision Science, 29, 659-684. https://doi.org/10.1111/j.1540-

5915.1998.tb01358.x

Carter, C.R., Kale, R., \& Grimm, C.M. (2000). Environmental purchasing and firm performance: an empirical investigation. Transportation Research Part E: Logistics and Transportation Review. 36 (3), 219-228. https://doi.org/10.1016/s1366-5545(99)00034-4

Chen, Y.S. (2008). The driver of green innovation and green image - green core competence. Journal of Business Ethics, 81(3), 531-543. https://doi.org/10.1007/s10551-007-9522-1

Choi, D., \& Hwang, T. (2015). The impact of green supply chain management practices on firm performance: The role of collaborative capability. Operations Management Research, 8(3-4), 69-83. https://doi.org/10.1007/s12063-0150100-x

Christmann, P., \& Taylor, G. (2001). Globalization and the environment: determinants of firm self-regulation in China. Journal of International Business Study, 32, 439-458. https://doi.org/10.2139/ssrn.277452

Darnall, N., Jolley, G.J., \& Handfield, R. (2008). Environmental management systems and green supply chain management: complements for sustainability? Business Strategy and the Environment, 17(1), 30-45. https://doi.org/10.1002/bse.557

de Sousa Jabbour, A.B.L., de Oliveira Frascareli, F.C., \& Jabbour, C.J.C. (2015). Green supply chain management and firms' performance: Understanding potential relationships and the role of green sourcing and some other green practices. Resources, Conservation and Recycling, 104, 366-374. https://doi.org/10.1016/j.resconrec.2015.07.017 
de Sousa Jabbour, ABEL., Jabbour, C.J.C., Latan, H., Teixeira, A.A., \& de Oliveira, J.H.C. (2014). Quality management, environmental management maturity, green supply chain practices and green performance of Brazilian companies with ISO 14001 certification: Direct and indirect effects. Transportation Research Part E: Logistics and Transportation Revien, 67, 39-51. https://doi.org/10.1016/j.resconrec.2015.07.017

Delmas, M. (2002). The diffusion of environmental management standards in Europe and in the United States: An institutional perspective. Policy Sciences, 35, 91-119.

Delmas, M., \& Montiel, I. (2009). Greening the supply chain: When is customer pressure effective? Journal of Economics and Management Strategy, 18(1), 171-201. https://doi.org/10.1111/j.1530-9134.2009.00211.x

Delmas, M., \& Toffel, M.W. (2004). Stakeholders and environmental management practices: an institutional framework. Business Strategy and the Environment, 13, 209-222. https://doi.org/10.1002/bse.409

DiMaggio, P., \& Powell, W.W. (1983). The iron cage revisited: Collective rationality and institutional isomorphism in organizational fields. American Sociological Revien, 48(2), 147-160. https://doi.org/10.1016/s0742-3322(00)17011-1

Dubey, R., Gunasekaran, A., Papadopoulos, T., \& Childe, S.J. (2015). Green supply chain management enablers: Mixed methods research. Sustainable Production and Consumption in Emerging Economies, 4, 72-88. https://doi.org/10.1016/j.spc.2015.07.001

Ehrhart, M.G. (2004). Leadership and procedural justice climate as antecedents of unit-level organisational citizenship behavior. Personal Psychology, 57, 61-94. https://doi.org/10.1111/j.1744-6570.2004.tb02484.x

Eksoz, C., Mansouri, S. A., \& Bourlakis, M. (2014). Collaborative forecasting in the food supply chain: A conceptual framework. International journal of production economics, 158, 120-135. https://doi.org/10.1016/j.ijpe.2014.07.031

Eltayeb, T.K., Zailani, S., Ramayah, T. (2011). Green supply chain initiatives among certified companies in Malaysia and environmental sustainability: investigating the outcomes. Resource, Conservation and Recycling, 55, 495-506. https://doi.org/10.1016/j.resconrec.2010.09.003

Ferrón-Vílchez, V., \& Darnall, N. (2016). Two are better than one: The link between management systems and business performance. Business Strategy and the Environment, 25(4), 221-240. https://doi.org/10.1002/bse.1864

González-Torre, P., Álvarez, M., Sarkis, J., \& Adenso-Díaz, B. (2010). Barriers to the implementation of environmentally oriented reverse logistics: evidence from the automotive industry sector. British Journal of Management, 21(4), 889-904. https://doi.org/10.1111/j.1467-8551.2009.00655.x

González-Benito, J., \& González-Benito, Ó. (2006). The role of stakeholder pressure and managerial values in the implementation of environmental logistics practices. International Journal of Production Research, 44(7), 1353-1373. https://doi.org/10.1080/00207540500435199

Green Jr, K.W., Zelbst, P.J., Meacham, J., \& Bhadauria, V.S. (2012). Green supply chain management practices: impact on performance. Supply Chain Management: An International Journal, 17(3), 290-305. https://doi.org/10.1108/13598541211227126

Green, K.W., Whitten, D., \& Inman, R.A. (2012). Aligning marketing strategies throughout the supply chain to enhance performance. Industrial Marketing Management, 41(6), 1008-1018.

Hair, J., Black, W., Babin, B., \& Anderson, R. (2010). Multivariate data analysis: a global perspective (7th ed.). New Jersey: Prentice Hall.

Harris, L.C., \& Crane, A. (2002). The greening of organizational culture: Management views on the depth, degree and diffusion of change. Journal of organizational change management, 15(3), 214-234.

https://doi.org/10.1108/09534810210429273

Homburg, C., Artz, M., \& Wieseke, J. (2012). Marketing performance measurement systems: does comprehensiveness really improve performance?. Journal of marketing, 76(3), 56-77. https://doi.org/10.1509/jm.09.0487 
Hsu, C.-C., Tan, K.C., Zailani, S.H.M., \& Jayaraman, V. (2013). Supply chain drivers that foster the development of green initiatives in an emerging economy. International Journal of Operations \& Production Management, 33, 656-688. https://doi.org/10.2139/ssrn.2881790

Jayaram, J., \& Avittathur, B. (2015). Green supply chains: A perspective from an emerging economy. International Journal of Production Economics, 164, 234-244. https://doi.org/10.1016/j.ijpe.2014.12.003

Jumadi, H., \& Zailani, S. (2010). Integrating green innovations in logistics services towards logistics service sustainability: a conceptual paper, Environmental Research Journal, 4(4), 261-271.

https://doi.org/10.3923/erj.2010.261.271

King, A.A., Lenox, M.J., \& Terlaak, A. (2005). The strategic use of decentralized institutions: Exploring certification with the ISO 14001 management standard. Academy of Management Journal, 48(6), 1091-1106.

https://doi.org/10.5465/amj.2005.19573111

Klassen, R., \& Johnson, F. (2004). The green supply chain. In New, S.J., \& Westbrook, R. (Eds.), Understanding Supply Chains: Concepts, critiques and futures (229-251). Oxford: Oxford University Press.

Lai, K.H., Wong, C.W.Y., \& Cheng, T.C.E. (2006). Institutional isomorphism and the adoption of information technology for supply chain management. Computers in Industry, 57 (1), 93-98. https://doi.org/10.1016/j.compind.2005.05.002

Lam, S.K., Kraus, F., \& Ahearne, M. (2010). The diffusion of market orientation throughout the organization: A social learning theory perspective. Journal of Marketing, 74(5), 61-79. https://doi.org/10.2139/ssrn.1584646

Leal, G.G., Casadesús, F.M., \& Pasola, J.V. (2003). Using environmental management systems to increase firms' competitiveness. Corporate Social Responsibility and Environmental Management, 10(2), 101-110. https://doi.org/10.1002/csr.32

Lewis, G.J., \& Harvey, B. (2001). Perceived environmental uncertainty: The extension of Miller's scale to the natural environment. Journal of Management Studies, 38(2), 201-234. https://doi.org/10.1111/1467-6486.00234

Lo, C.W.H., \& Leung, S.W. (2000). Environmental agency and public opinion in Guangzhou: the limits of a popular approach to environmental governance. The China Quartery, 677-704. https://doi.org/10.1017/s0305741000014612

Luthra, S., Garg, D., \& Haleem, A. (2015). An analysis of interactions among critical success factors to implement green supply chain management towards sustainability: An Indian perspective. Resources Policy, 46(1), 37-50. https://doi.org/10.1016/j.resourpol.2014.12.006

Min, H., \& Galle, W.P. (2001). Green purchasing practices of US firms. Internatioanl Journal of Operations and Production Management, 21, 1222-1238. https://doi.org/10.1108/eum0000000005923

Nidumolu, R., Prahalad, C.K., \& Rangaswami, M.R. (2009). Why sustainability is now the key driver of innovation. Harvard business revien, 87(9), 56-64.

O’Cass, A., \& Weerawardena, J. (2010). The effects of perceived industry competitive intensity and marketing-related capabilities: drivers of superior brand performance. Industrial Marketing Management, 39, $571-581$. https://doi.org/10.1016/j.indmarman.2009.04.002

Petersen, J.A., \& Kumar, V. (2009). Are product returns a necessary evil? Antecedents and consequences. Journal of Marketing, 73(3), 35-51. https://doi.org/10.1509/jmkg.73.3.35

Porter, M.E. \& Van der Linde, C. (1995). Green and competitive: ending the stalemate. Harvard Business Review, 73(5), 120-134.

Rivera, J. (2004). Institutional pressures and voluntary environmental behavior in developing countries: evidence from the Costa Rican hotel industry. Society and Natural Resources 17, 779-797. https://doi.org/10.1080/08941920490493783

Sarkis, J., Zhu, Q., \& Lai, K. (2011). An organizational theoretic review of green supply chain management literature. International Journal of Production Economics, 130, 1-15. https://doi.org/10.1016/j.ijpe.2010.11.010 
Seuring, S., \& Müller, M. (2008). From a literature review to a conceptual framework for sustainable supply chain management. Journal of Cleaner Production, 16(15), 1699-1710. https://doi.org/10.1016/j.jclepro.2008.04.020

Sheu, J.B., \& Talley, W.K. (2011). Green supply chain management: trends, challenges, and solutions. Transportation Research Part E: Logistic and Transportation Review, 47(6), 791-792. https://doi.org/10.1016/j.tre.2011.05.014

Spicer, A.J., \& Johnson, M.R. (2004). Third-party demanufacturing as a solution for extended producer responsibility. Journal of Cleaner Production, 12(1), 37-45. https://doi.org/10.1016/s0959-6526(02)00182-8

Testa, F., \& Iraldo, F. (2010). Shadows and lights of GSCM (Green Supply Chain Management): determinants and effects of these practices based on a multi-national study. Journal of Cleaner Production, 18, 953-962. https://doi.org/10.1016/j.jclepro.2010.03.005

Toffel, M.W. (2004). Strategie management of product recovery. California management revien, 46(2), $120-141$. https://doi.org/10.2307/41166214

Truffer, B., \& Coenen, L. (2012). Environmental innovation and sustainbility transitions in regional studies, Regional Study, 46(1), 1-2. https://doi.org/10.1080/00343404.2012.646164

Vachon, S., \& Klassen, R.D. (2006). Extending green practices across the supply chain: the impact of upstream and downstream integration. International Journal of Operations and Production Management, 26(7), 795-821. https://doi.org/10.1108/01443570610672248

Walker, H., Sisto, L.D., \& McBain, D. (2008). Drivers and barriers to environmental supply chain management practices: lessons from the public and private sectors. Journal of Purchasing and Supply Chain Management, 14, 69-85. https://doi.org/10.1016/j.pursup.2008.01.007

Wong, C.W., Lai, K.H., Lun, Y.V., \& Cheng, T.C.E. (2012). A study on the antecedents of supplier commitment in support of logistics operations. International Journal of Shipping and Transport Logistics, 4(1), 5. https://doi.org/10.1504/ijstl.2012.044132

Yu, W., Chavez, R., Feng, M., \& Wiengarten, F. (2014). Integrated green supply chain management and operational performance. Supply Chain Management: An International Journal, 19, 683-696. https://doi.org/10.1108/scm-07-20130225

Zailani, S.H.M., Eltayeb, T.K., Hsu, C.C., \& Choon Tan, K. (2012). The impact of external institutional drivers and internal strategy on environmental performance. International Journal of Operations \& Production Management, 32(6), 721-745. https://doi.org/10.1108/01443571211230943

Zhan, Y., Tan, K.H., Ji, G., Chung, L., \& Chiu, A.S. (2018). Green and lean sustainable development path in China: Guanxi, practices and performance. Resources, Conservation and Recycling, 128, 240-249.

https://doi.org/10.1016/j.resconrec.2016.02.006

Zhu, Q., Sarkis, J., \& Lai, K.-H. (2012). Examining the effects of green supply chain management practices and their mediations on performance improvements. International Journal of Production Research, 50(5), 1377-1394. https://doi.org/10.1080/00207543.2011.571937

Zhu, Q., Sarkis, J., Cordeiro, J. J., \& Lai, K.-H. (2008a). Firm-level correlates of emergent green supply chain management practices in the Chinese context. Omega, 36, 577-591. https://doi.org/10.1016/j.omega.2006.11.009

Zhu, Q., Sarkis, J., \& Lai, K. (2007). Green supply chain management: pressures, practices and performance within the Chinese automobile industry. Journal of Cleaner Production, 15(11-12), 1041-1052. https://doi.org/10.1016/j.jclepro.2006.05.021

Zhu, Q., Sarkis, J., \& Lai, K.H. (2008b). Confirmation of a measurement model for green supply chain management practices implementation. International Journal of Production Economy, 111(2), 261-273. https://doi.org/10.1016/j.ijpe.2006.11.029

Zhu, Q., Sarkis, L., \& Lai, K. (2013). Institutional-based antecedents and performance outcomes of internal and external green supply chain management practices. Journal of Purchasing and Supply Chain Management, 19 (2), 106-117. https://doi.org/10.1016/j.pursup.2012.12.001 
Zsidisin, G.A., \& Siferd, S.P. (2001). Environmental purchasing: a framework for theory development. European Journal of Purchasing \& Supply Management, 7(1), 61-73. https://doi.org/10.1016/s0969-7012(00)00007-1

Zsidisin, G.A., Melnyk, S.A., \& Ragatz, G.L. (2005). An institutional theory perspective of business continuity planning for purchasing and supply management. International Journal of Production Research, 43, 3401-3420. https://doi.org/10.1080/00207540500095613

Journal of Industrial Engineering and Management, 2019 (www.jiem.org)

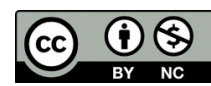

Article's contents are provided on an Attribution-Non Commercial 4.0 Creative commons International License. Readers are allowed to copy, distribute and communicate article's contents, provided the author's and Journal of Industrial Engineering and Management's names are included. It must not be used for commercial purposes. To see the complete license contents, please visit https://creativecommons.org/licenses/by-nc/4.0/. 